Article

\title{
Analyzing the Global Risks for the Financial Crisis after the Great Depression Using Comparative Hybrid Hesitant Fuzzy Decision-Making Models: Policy Recommendations for Sustainable Economic Growth
}

\author{
Hasan Dinçer ${ }^{(\mathbb{D}}$, Serhat Yüksel * (1) and Seçil Şenel \\ School of Business, İstanbul Medipol University, Kavacık Mah. Ekinciler Cad. No.19 Kavacık Kavşağı—Beykoz, \\ 34810 İstanbul, Turkey; hdincer@medipol.edu.tr (H.D.); secilsenel@medipol.edu.tr (S.S..) \\ * Correspondence: serhatyuksel@medipol.edu.tr; Tel.: +90-216-681-5000
}

Received: 8 July 2018; Accepted: 25 August 2018; Published: 2 September 2018

\begin{abstract}
The aim of this study is to analyze the effects of global risks on financial crises. For this purpose, five different outstanding crises after the Great Depression of 1929 are taken into the consideration. Additionally, four different dimensions are selected regarding global risk by considering the Global Risk Report. Moreover, the hesitant fuzzy DEMATEL, the hesitant fuzzy VIKOR, and the hesitant fuzzy TOPSIS methodologies are used to reach this objective. We concluded that, with respect to global risks, the industry-based dimension has the highest importance in comparison to other dimensions. In addition, we also identified that the 2010 European debt crisis and the 1982 Latin American debt crisis were the most influenced crises in terms of global risk. The main reason for this is that the macroeconomic problems such as high inflation and unemployment had negative impacts on the industries of these countries. Another important point is that the results of the hesitant fuzzy VIKOR and hesitant fuzzy TOPSIS models are quite different, but they are the most similar when the experts do not reach the consensus. This situation shows that this analysis is quite appropriate with respect to the hesitant approach. While considering these aspects, we recommended that countries should firstly focus on the solutions related to industry level problems in order to minimize the global risk. Owing to this issue, it can be more possible to reach sustainable economic growth in the world.
\end{abstract}

Keywords: global risk; financial crisis; hesitant fuzzy DEMATEL; hesitant fuzzy TOPSIS; hesitant fuzzy VIKOR; sustainable economic growth

\section{Introduction}

Globalization decreases the economic borders among countries. Therefore, it can be said that markets in different countries have become more integrated, especially in the last years due to this condition. This situation has many advantages for the players in the financial system, such as giving them a chance to enter new markets. However, it is also obvious that it increases the significance of the global risks owing to the volatility in these markets. Global risks include the risks which affect the world market in a broad sense. In other words, it refers to the risks that have a negative and crucial influence on many different countries at the same time [1].

According to the Global Risk Report (https://www.weforum.org/reports/the-global-risksreport-2018) created by the World Economic Forum, there are five different criteria that constitute a global risk. First of all, a risk should affect many different regions in the world to be a global risk, this is referred to as having a "global scope". Similar to this situation, it is expected that a global risk has an influence on various industries. Thirdly, there should be a high level of uncertainty for a risk to 
be considered a global risk. The fourth criterion of the global risk is that it causes economic damage at an important level. Finally, global risks should be managed with the help of a multi-stakeholder approach because it has significant negative effects on many different parties [2].

As it can be understood from the issues emphasized above, global risks may cause significant financial crises if they cannot be managed effectively. For instance, if there is income inequality in the countries and it has an increasing trend, this situation can be accepted as the reason for a financial crisis. On the other side, financial crises also have an important influence on global risks. As an example, a significant financial crisis may lead to a high level of unemployment and social problems, such as migration.

Parallel to these aspects, the purpose of this study is to analyze the global risks of financial crises. Within this framework, the outstanding financial crises after the Great Depression of 1929 are taken into the consideration. For this purpose, the hesitant fuzzy "decision making trial and evaluation laboratory" (DEMATEL), the hesitant fuzzy "Technique for Order Preference by Similarity to Ideal Solution" (TOPSIS), and the "Vlsekriterijumska Optimizacija I Kompromisno Resenje" (VIKOR) approaches are used comparatively. As a result of this analysis, it will be possible to provide policy recommendations for sustainable economic growth. By making a very significant analysis of the world's economic development with an original methodology, we aimed to make a contribution to the literature.

This study consists of five different sections. After the introduction, the historical background of the financial crisis mentioned above is given in the second part. Moreover, similar studies in the literature are detailed in the third part so that the missing area in the literature can be underlined. In the fourth section, an application of the methodology on the selected financial crisis is given. Within this scope, firstly, the methodologies used in this study are detailed and after that, the analysis results are shared. In the final part, the necessary recommendations are presented according to the results of the analysis.

\section{Historical Background of Financial Crisis}

A financial crisis refers to the situation in which there is a dramatic decrease in the values of some financial assets. This condition has negative effects on many different parties in the financial system. As a result of this issue, lots of the companies go bankrupt and many different people become unemployed. Therefore, it can be said that a financial crisis is a very crucial aspect for countries, so necessary actions should be taken in order to prevent this event [3].

In the literature, many different conditions are accepted as indicators of the financial crisis. First of all, if the inflation rate is too high in a country, it is thought of as a factor that may cause a financial crisis because it increases the uncertainty. Additionally, it has been stated in many different studies that there is a positive correlation between low economic growth and financial crises. Moreover, a volatility in the exchange rate and a high current account deficit amount can also be accepted as indicators of these crises [4-6].

There are lots of different crises in history. The important point is that these crises did not only occur in developing countries. It can also be seen that some developed economies experienced financial crises in the past, such as the USA, Japan, and Sweden. In addition to these aspects, there are some types of financial crises that affect only the countries in which the crisis started in. Nonetheless, it was also identified that some crises also had an influence on many different countries, such as the Asian crisis and the global mortgage crisis. In this part of the study, some important financial crises which have affected many different countries are detailed.

The 1973 Oil Crisis: Oil is accepted as one of the most significant factors that affect the economy of the world. Because of this situation, it could be seen that it causes many different political problems between countries. In 1973, the Organization of Arab Petroleum Exporting Countries started an oil embargo for countries that support Israel in the Yom Kippur War, such as the United States, the United Kingdom, Canada, Japan, and the Netherlands. Due to this situation, the price of oil 
increased dramatically, causing an oil crisis in the world. This crisis mainly affected European countries negatively in many ways, such as causing a decrease in the industrial production rate and an increase in the unemployment rate [7].

The 1982 Latin American Debt Crisis: In the 1980s, some Latin American countries borrowed too much from international institutions. The main purpose of this debt for these countries was to improve their infrastructure. However, the Latin American countries could not pay their debts. It is thought that the origins of the 1982 Latin American debt crisis started with the oil crisis that occurred in 1973. The main reason behind this situation is that due to high oil prices, there was a high increase in the inflation rate, which had a negative influence on the economic performance of these countries. Owing to this issue, there was a significant amount of capital outflow from these countries. American banks also had important losses because they were the main institutions that gave debt to the Latin American countries [8].

The 1997 Asian Financial Crisis: Most Asian countries fixed their domestic currencies to the American dollar at the beginning of the 1990s. There was a significant increase in the value of the American dollar during these years. This situation led to the increase in the value of the currencies of Asian countries because they had fixed their domestic currencies to the American dollar. Due to this condition, export products became more expensive in the international market. Another important issue in this period is that there was a devaluation in China which made Chinese export products cheaper. Additionally, there was an economic recession in Japan, to where Asian countries mainly exported goods. Owing to these issues, Asian countries had a significant current account deficit. As a result of this issue, there was an important capital outflow from Asian countries. In order to prevent this problem, firstly, Thailand depreciated its domestic currency. After that, Indonesia, South Korea, Malaysia, and the Philippines implemented the same policy. As a result of this devaluation, banks in these countries had significant losses because they had an important amount of foreign debt [9].

The 2008 Global Mortgage Crisis: The United States suffered from the dot.com crisis in 2000. The US Central Bank (FED) decreased the interest rate to a historic low to minimize the negative effects of this crisis. This situation caused mortgage loans to increase. However, it could be seen that these loans were not only given to the people who had high credibility. Additionally, people with a high risk of defaulting (subprime) also used these loans. Another important point in this period was that banks issued mortgage bonds in order to give a higher amount of loans. In this period, the FED decided to increase the interest rates, which lead to higher installments for people who had used loans. As a result of this situation, they could not pay their debt to the banks. Consequently, a lot of banks and insurance companies went bankrupt all around the world [10].

The 2010 European Debt Crisis: Each European country had to pay an interest rate according to their credibility before joining the Euro system. After this condition, there emerged a unique interest rate which was the same for all European Union countries. As a result of this, a lot of countries got a chance to borrow at a lower cost than they had been able to before. This situation caused significant problems in the fiscal disciplines for some of these countries and after a period, they found themselves unable to pay their debt. The most important effects of the European debt crisis were seen in Greece. The GDP growth rate dramatically went down and the credit rating of Greece decreased to a historic low. In addition to Greece, there were also some other European Union countries which had financial problems, such as Italy, Spain, Cyprus, and Portugal [11].

\section{A Literature Review of Global Risks and Financial Crises}

Global risk is such a popular subject in the literature that it is assessed in many different studies. Some of these studies focus on the evaluation of global risk in different regions. For example, Pap and Homolya [12] made a study regarding the measurement of global risk. They concluded that the CDS spread is the most important indicator for the countries that affect global risk. Similar to this study, Nasr et al. [13], Korotaev et al. [14], Acosta et al. [15], and Shostya and Banai [16] also tried to evaluate 
the global risk of different countries. Additionally, Avdjiev et al. [17] analyzed that the dollar exchange rate is a significant factor of global risk.

Moreover, it can also be understood that some other studies aim to understand the factors that have an effect on global risk. For instance, Mensi et al. [18] made a study in order to understand the determinants of global risk. With the help of the dynamic panel threshold model, a significant relationship between stock returns and global risk in some of these countries was identified. Additionally, Liu et al. [19] concluded that the oil price volatility was an important influence on global risk. On the other hand, Chiu and Lee [20] underlined the importance of public debt on global risk. Additionally, Wang and Huang [21] defined that economic growth is an important aspect that affects global risk.

In addition to these studies, some studies in the literature underline the impacts of global risk on other variables. As an example, Sahi and Rasheed [22] tried to understand the impact of global risk on Pakistan and they reached a conclusion that global risk has a negative influence on the bond market. Furthermore, Lee [23] identified that high global risk has an important effect on the income inequality of the countries. Moreover, Cervelló-Royo et al. [24] identified that the high global risk of the countries negatively affects tourism activities. Additionally, Naifar [25] stated that global risk has an effect on Islamic index dynamics.

Similar to global risk, the subject of financial crises has attracted the attention of many different researchers in the literature. Most of the studies on this subject aim to understand the main reasons for financial crises. For example, Jackson [26] analyzed the details of the Asian financial crisis that occurred in 1997 and reached the conclusion that the volatility in the currency exchange rate was the main reason for this crisis. Moreover, Golub et al. [4], Keffala [5], and Knights and McCabe [6] determined that the derivatives played a key role in the 2008 global financial crisis. Additionally, Gilchrist et al. [27] and Mera and Renaud [28] underlined the importance of the inflation effect on financial crises. Additionally, Ferrero [29] and Stockhammer et al. [30] determined that the current account deficit is the main indicator of the financial crises.

Furthermore, it can also be seen that some studies aim to analyze the impacts of financial crises. For instance, Claessens and Van Horen [31] concluded that financial crises have an important influence on banking globalization. Additionally, Ramcharan et al. [32] underlined that financial crises have a negative effect on consumer credit supply. Additionally, Zouaghi et al. [33] identified that financial crises decrease the innovation performance of the companies. Similarly, Malik and Ghosh [34] emphasized that the financial crisis has a negative influence on the economic growth of countries.

While considering the information given above, there are lots of studies that analyze the subjects of global risk and financial crisis. These studies also focus on the reasons for and the impacts of these subjects in a detailed manner. However, it is identified that there is a need for a new study which focuses on whether financial crises affect global risk.

\section{An Analysis of the Selected Financial Crisis}

\subsection{Model Construction}

The details of the analysis process are illustrated in Figure 1.

First of all, the dimensions of the global risk are identified. For this purpose, four different dimensions are defined by considering the important points in the Global Risk Report. The details of these dimensions are given in Table 1. 


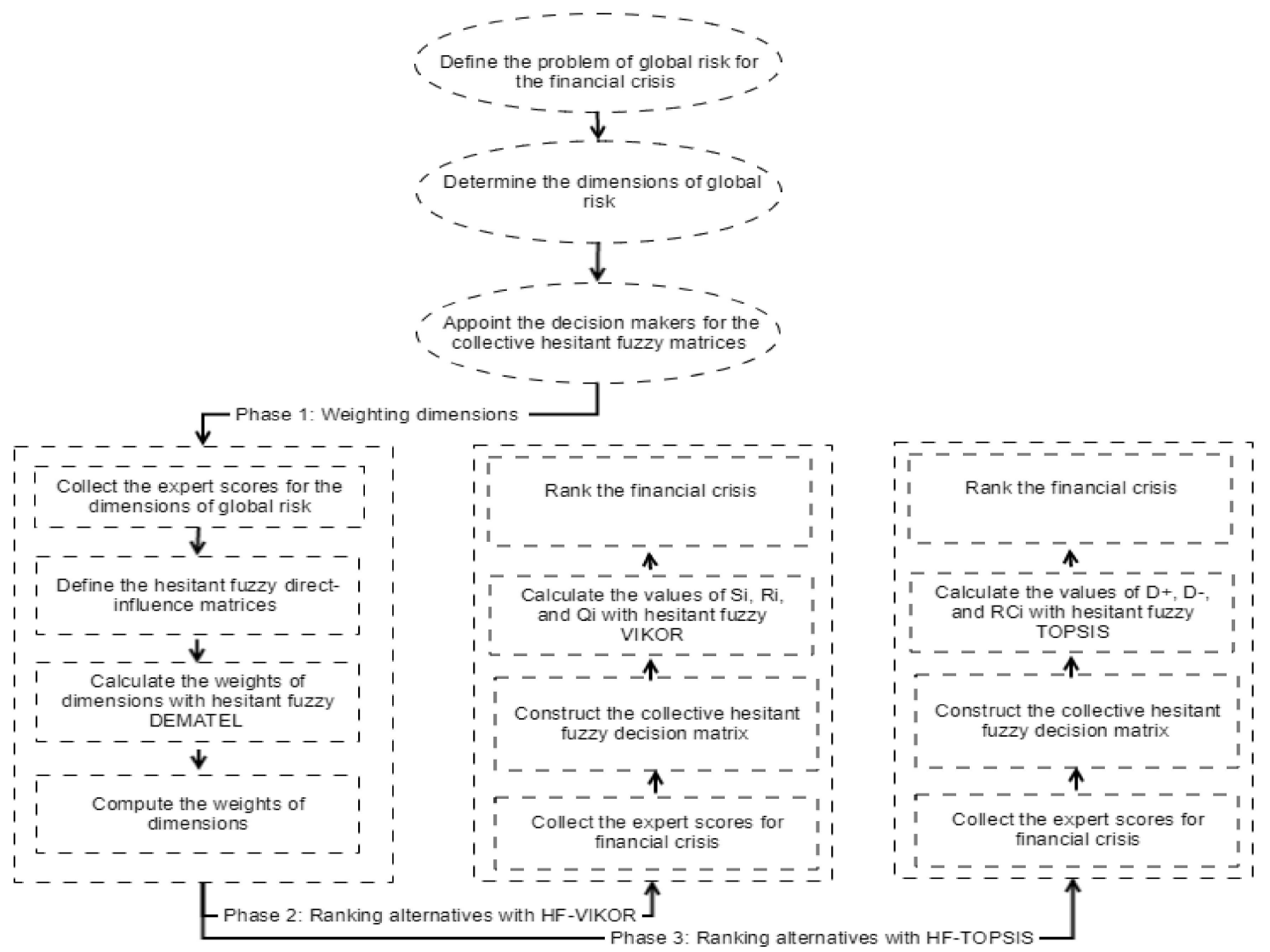

Figure 1. The flowchart of the proposed hybrid hesitant fuzzy decision-making approach.

Table 1. The proposed dimensions of global risk.

\begin{tabular}{ccc}
\hline Dimension & Definition & Supported Literature \\
\hline Economy-based (D1) & $\begin{array}{c}\text { It includes the macroeconomic problems, } \\
\text { such as high inflation and unemployment. }\end{array}$ & $\begin{array}{c}\text { Naifar [25], Ordoñez-Callamand et al. [35], } \\
\text { Berger et al. [36] }\end{array}$ \\
\hline Industry-based (D2) & $\begin{array}{c}\text { It refers to the negative conditions that } \\
\text { affect some of the significant industries in } \\
\text { the country. }\end{array}$ & $\begin{array}{c}\text { Rehman et al. [37], Wilson [38], } \\
\text { Abune'Meh et al. [39] }\end{array}$ \\
\hline Firm-based (D3) & $\begin{array}{c}\text { It shows the problems which have } \\
\text { important negative impacts on the } \\
\text { financial performance of the companies. }\end{array}$ & $\begin{array}{c}\text { Wilson and Kinghorn [40], Talarico et al. [41], } \\
\text { Awasthi et al. [42] }\end{array}$ \\
\hline Vagueness (D4) & It refers to the uncertainty in the market. & $\begin{array}{c}\text { Aven and Cox [2], Moser and Kasperson [43], } \\
\text { Balbás et al. [44] }\end{array}$ \\
\hline
\end{tabular}

Table 1 gives information that the four different dimensions for global risk are determined by evaluating the factors emphasized in the Global Risk Report. The economy-based condition (D1) is the first dimension, which considers macroeconomic problems of the countries, such as inflation, unemployment, and the current account deficit $[35,36]$. In addition to the economy-based factors, the industry-based situation (D2) is the second dimension, which includes the negative conditions that have an influence on the industries in the country [37,38]. Moreover, the firm-based aspect (D3) has negative impacts on the financial performance of the companies and is chosen as the third dimension [41,42]. The final dimension is the vagueness (D4) that refers to the uncertainty in the market conditions $[43,44]$. After determining the dimensions, the decision makers are appointed in order to make an assessment. 
In this circumstance, the hesitant fuzzy DEMATEL approach is taken into consideration in order to weigh the determined dimensions. In addition to identifying the importance of the global risk dimensions, it aimed to analyze the impact of global risk on the financial crisis. Within this framework, five different financial crises after the Great Depression of 1929 are selected. In this selection process, the financial crises which were significant on the global basis are included in the analysis, such as the 1973 Oil Crisis (A1), the 1982 Latin American Debt Crisis (A2), the 1997 Asian Financial Crisis (A3), the 2008 Global Mortgage Crisis (A4), and the 2010 European Debt Crisis (A5). Furthermore, these crises are ranked by using the hesitant fuzzy VIKOR and the hesitant fuzzy TOPSIS methodologies. The details of all the methods used in this study are given in the following section.

\subsection{Methods Used in the Analysis}

\subsubsection{Hesitant Fuzzy DEMATEL}

This methodology was introduced by the Geneva Research Centre of the Battelle Memorial Institute. This methodology is mainly used to identify the relationship between the factors under a complex situation. In the first step of this analysis, the relation between the dimensions is rated by considering the subset of $[0,1]$. Within this context, the decision makers make their assessment. In the second step, the collective hesitant fuzzy initial direct-relation fuzzy matrix is calculated by considering the evaluations of the decision makers. The details of this matrix $(\widetilde{Z})$ are given below. In this matrix, $\widetilde{Z}_{i j}$ refers to the degree of influence regarding hesitant values [45,46].

$$
\widetilde{Z}=\left[\begin{array}{ccccc}
0 & \widetilde{Z}_{12} & \cdots & \cdots & \widetilde{Z}_{1 n} \\
\widetilde{Z}_{21} & 0 & \cdots & \cdots & \widetilde{Z}_{2 n} \\
\vdots & \vdots & \ddots & \ddots & \vdots \\
\vdots & \vdots & \vdots & \ddots & \vdots \\
\widetilde{Z}_{n 1} & \widetilde{Z}_{n 2} & \cdots & \cdots & 0
\end{array}\right]
$$

This matrix is provided by the $k$ th expert. In this process, the average fuzzy scores are used, demonstrated in Equation (2).

$$
\widetilde{Z}^{k}=\frac{\widetilde{Z}^{1}+\widetilde{Z}^{2}+\widetilde{Z}^{3}+\cdots \widetilde{Z}^{l}}{l}, k=(1,2, \ldots, l)
$$

This equation aggregates the opinions of $l$ different experts. Therefore, the group decision matrix can be formed [47]. In the third step, the direct effect matrix is normalized with the help of the following equations.

$$
\widetilde{x}=\left[\begin{array}{ccccc}
\widetilde{x}_{11} & \widetilde{x}_{12} & \cdots & \cdots & \widetilde{x}_{1 n} \\
\widetilde{x}_{21} & \widetilde{x}_{22} & \cdots & \cdots & \widetilde{x}_{2 n} \\
\vdots & \vdots & \ddots & \ddots & \vdots \\
\vdots & \vdots & \vdots & \ddots & \vdots \\
\widetilde{x}_{n 1} & \widetilde{x}_{n 2} & \cdots & \cdots & \widetilde{x}_{n n}
\end{array}\right]
$$

where

$$
\widetilde{x}_{i j}=\frac{\widetilde{z}_{i j}}{r} \text { and } r=\max _{1 \leq i \leq n}\left(\sum_{j=1}^{n} \widetilde{z}_{i j}\right)
$$

In the fourth step, the total influence matrix $(T)$ is developed by using the equations given below.

$$
\begin{aligned}
& T=N+N^{2}+N^{2}+\cdots+N^{h} \\
= & N\left(I+N+N^{2}+\cdots+N^{h-1}\right)(I-N)(I-N)^{-1}
\end{aligned}
$$




$$
T=N\left(I-N^{h}\right)(I-N)^{-1}=N(I-N)^{-1}, \text { when } \lim _{h \rightarrow \infty} N^{h}=[0]_{n \times n}
$$

In the final step, the influential network relation map is computed. The details of the calculation process are given below.

$$
\begin{gathered}
T=\left[t_{i j}\right]_{n \times n^{\prime}} i, j=1,2, \ldots, n \\
r=\left[\sum_{j=1}^{n} t_{i j}\right]_{n \times 1}=\left(r_{i}\right)_{n \times 1}=\left(r_{1}, \ldots, r_{i}, \ldots, r_{n}\right) \\
y=\left[\sum_{i=1}^{n} t_{i j}\right]_{1 \times n}^{\prime}=\left(y_{j}\right)_{1 \times n}^{\prime}=\left(y_{1}, \ldots, y_{i}, \ldots, y_{n}\right)
\end{gathered}
$$

The hesitant fuzzy DEMATEL method was preferred in some different studies in the literature. For example, Dinçer et al. [48], Gitinavard et al. [49], and Wu et al. [50] considered this methodology to make an analysis in the energy industry.

\subsubsection{Hesitant Fuzzy VIKOR}

The VIKOR methodology is mainly used to define the best solution under a complex situation. In other words, this approach is preferred to find the best alternative by ranking all alternatives according to the defined conditions. On the other hand, the hesitant fuzzy VIKOR gives information about the extended method regarding hesitant fuzzy sets [51].

In the first step of the hesitant fuzzy VIKOR methodology, the evaluations of the decision makers are provided between the values of 0 and 1 . After that, the decision matrix of the multi-criteria problem under the HFSs is generated with the help of the evaluation results. The details of this matrix are given in Equation (10).

$$
D=\begin{gathered}
\text { C1 C2 C3 .. Cn } \\
A_{1} \\
A_{2} \\
A_{3} \\
\vdots \\
A_{m}
\end{gathered}\left[\begin{array}{cccccc}
h_{11} & h_{12} & h_{13} & & \ldots & h_{1 n} \\
h_{21} & h_{22} & h_{23} & & \ldots & h_{2 n} \\
h_{31} & h_{32} & h_{33} & & \ldots & h_{3 n} \\
\vdots & \vdots & \vdots & \ddots & & \vdots \\
h_{m 1} & h_{m 2} & h_{m 3} & & \ldots & h_{m n}
\end{array}\right]
$$

In this matrix, $A$ refers to the alternatives whereas $C$ gives information about the criteria. On the other hand, the $h$ values show the evaluation of the decision makers. The calculation process for the ratings is defined in Equation (11).

$$
h_{i j}=\frac{1}{k}\left[\sum_{e=1}^{n} h_{i j}{ }^{e}\right], i=1,2,3, \ldots, m
$$

In the second step, the best value $h^{+}$and worst value $h^{-}$are determined by using the following equations.

$$
\begin{gathered}
h_{J}^{+}=\max _{i} h_{i j} \text {, and } h_{j}^{-}=\min _{i} h_{i j}, \\
A^{+}=\left\{h_{1}^{+}, \ldots, h_{n}^{+}\right\}
\end{gathered}
$$

where

$$
\begin{gathered}
h_{j}^{+}=\cup_{i=1}^{m} h_{i j}=\cup_{\gamma 1 j \epsilon j_{i j}, \ldots, \gamma_{m j} \epsilon} h_{m j} \max \left\{\gamma_{1 j}, \ldots, \gamma_{m j}\right\} j=1,2, \ldots, n \\
A^{-}=\left\{h_{1}^{-}, \ldots, h_{n}^{-}\right\}
\end{gathered}
$$

where

$$
h_{j}^{-}=\cap_{i=1}^{m} h_{i j}=\cup_{\gamma 1 j \epsilon j_{i j}, \ldots, \gamma_{m j} \in h_{m j}} \min \left\{\gamma_{1 j}, \ldots, \gamma_{m j}\right\} j=1,2, \ldots, n
$$


In the third step, the mean group utility $(S)$ and maximal regret $(R)$ are calculated with the following equations.

$$
\begin{gathered}
S_{i}=\sum_{i=1}^{n} w_{j} \frac{\left(\left|h_{j}^{+}-h_{i j}\right|\right)}{\left(\left|h_{j}^{+}-h_{j}^{-}\right|\right)} \\
R_{i}=\max _{j}\left[w_{j} \frac{\left(\left|h_{j}^{+}-h_{i j}\right|\right)}{\left(\left|h_{j}^{+}-h_{j}^{-}\right|\right)}\right]
\end{gathered}
$$

Moreover, in the fourth step, the value of $Q_{i}$ is calculated. In this process, Equation (19) is taken into the consideration.

$$
Q_{i}=v\left(S_{i}-S^{*}\right) /\left(S^{-}-S^{*}\right)+(1-v)\left(R_{i}-R^{*}\right) /\left(R^{-}-R^{*}\right)
$$

In this equation, $S^{*}$ and $R^{*}$ represent the minimum values of $S$ and $R$. On the other side, $v$ shows the weight of the maximum group utility while $(1-v)$ represents the weight for individual regret.

In the final step, the $S, R$, and $Q$ values are sorted. Within this framework, two different conditions should be satisfied. According to the first condition, the acceptable advantage is detailed in the following equation.

$$
Q\left(A^{(2)}\right)-Q\left(A^{(1)}\right) \geq 1 /(j-1)
$$

In this equation, $A^{(2)}$ shows the second position in the alternatives. In addition to this situation, the second condition is related to the acceptable stability in the decision making. The solution is accepted as stable in the case of the maximum group utility (when $v>0.5$ is needed), "by consensus" $(v \approx 0.5)$, or "with veto" $(v<0.5)$.

If the first condition cannot be satisfied, the alternatives $A^{(1)}, A^{(2)} \ldots, A^{(M)}$ are selected. In this case, $A(m)$ represents $Q\left(A^{(M)}\right)-Q\left(A^{(1)}\right)<1 /(j-1)$. Additionally, if the second condition cannot be satisfied, the alternatives $A^{(1)}$ and $A^{(2)}$ are selected. It can be seen that the hesitant fuzzy VIKOR method was used in some studies in the literature. For instance, Liao and Xu [52], Ren et al. [53], and Zhang et al. [54] made a study regarding decision making under an uncertain environment with the help of this approach.

\subsubsection{Hesitant Fuzzy TOPSIS}

This method was developed by Hwang and Yoon [55] with the aim of ranking the alternatives in order to reach the best one. On the other hand, the hesitant fuzzy TOPSIS is the approach that evaluates different alternatives by considering the hesitant fuzzy sets. In the first step, the collective hesitant fuzzy decision matrix is generated by considering the evaluations of the decision makers. In the second step, the ideal and negative solutions are calculated according to the cost and benefit criteria. In this process, the following equations are considered.

$$
A^{+}=\left\{h_{1}^{+}, \ldots, h_{n}^{+}\right\}
$$

where

$$
\begin{gathered}
h_{j}^{+}=\cup_{i=1}^{m} h_{i j}=\cup_{\gamma 1 j \epsilon \epsilon_{i j}, \ldots, \gamma_{m j}} h_{m j} \max \left\{\gamma_{1 j}, \ldots, \gamma_{m j}\right\} j=1,2, \ldots, n \\
A^{-}=\left\{h_{1}^{-}, \ldots, h_{n}^{-}\right\}
\end{gathered}
$$

where

$$
h_{j}^{-}=\cup_{i=1}^{m} h_{i j}=\cup_{\gamma 1 j \epsilon j_{i j}, \ldots, \gamma_{m j} \in h_{m j}} \min \left\{\gamma_{1 j}, \ldots, \gamma_{m j}\right\} j=1,2, \ldots, n
$$

In the third step, the separation of each alternative from the ideal solution is weighted with the help of the following equations.

$$
B_{i}^{+}=w_{i} \times\left\|h_{i j}-h_{j}^{+}\right\|
$$




$$
B_{i}^{-}=w_{i} \times\left\|h_{i j}-h_{j}^{-}\right\|
$$

In these equations, $w$ gives information about the weight of the criteria. Furthermore, in the fourth step, the distances of the best and the worst alternatives for each criterion are calculated. For this purpose, Equations (27) and (28) are taken into consideration.

$$
\begin{aligned}
& D_{i}^{+}=\sum_{j=1}^{n} B_{i}^{+} \\
& D_{i}^{-}=\sum_{j=1}^{n} B_{i}^{-}
\end{aligned}
$$

On the other side, in the last step, the relative closeness to the ideal solution is calculated with the help of Equation (29).

$$
R C_{i}=\frac{D_{i}^{-}}{D_{i}^{+}+D_{i}^{-}} \text {for } i=1,2, \ldots, m \text { and } 0 \leq R C_{i} \leq 1
$$

As it can be understood, the hesitant fuzzy VIKOR and hesitant fuzzy TOPSIS methodologies have some similarities. Within this framework, it can be seen that the set of Equations (14)-(17) and (22)-(25) are almost the same. However, after these equations, it is possible to see the differences between these two methodologies. In the hesitant fuzzy VIKOR approach, the mean group utility and maximal regret are taken into consideration to reach the objective. On the other hand, with respect to the hesitant fuzzy TOPSIS model, the separation of each alternative from the ideal solution is calculated for this purpose. In the literature, the hesitant fuzzy TOPSIS method was taken into consideration by some studies. As an example, Cevik Onar et al. [56], Yavuz et al. [57], and Senvar et al. [58] used this approach with the aim of selecting strategic decisions for different industries.

\subsection{Analysis Results}

Weighting the dimensions of the global risk with hesitant fuzzy DEMATEL:

In the first phase, the dimensions of the global risk are weighted by using the hesitant fuzzy DEMATEL method. In order to reach this objective, four different decision makers are appointed. These people consist of academicians from the reputable universities of Europe. Firstly, the collective hesitant fuzzy direct-influence matrix is calculated for the dimensions of the global risk by considering the assessments of the decision makers. The details of this matrix are given in Table 2.

Table 2. The collective hesitant fuzzy direct-influence matrix for the dimensions of global risk.

\begin{tabular}{ccccc}
\hline Dimensions & D1 & D2 & D3 & D4 \\
\hline Economy-based (D1) & $\{0\}$ & $\{0.6,0.7\}$ & $\{0.5,0.6\}$ & $\{0.5,0.6\}$ \\
Industry-based (D2) & $\{0.5,0.6,0.7\}$ & $\{0\}$ & $\{0.6,0.7\}$ & $\{0.5,0.6\}$ \\
Firm-based (D3) & $\{0.4,0.5\}$ & $\{0.6,0.7\}$ & $\{0\}$ & $\{0.4,0.5\}$ \\
Vagueness (D4) & $\{0.6,0.7,0.8\}$ & $\{0.6,0.7,0.8\}$ & $\{0.6,0.7\}$ & $\{0\}$ \\
\hline
\end{tabular}

Table 2 explains the different views of the decision makers. If there are two different values between the parentheses, four different decision makers have given two different evaluations. After that, the crisp direct-influence matrix is created and the details are demonstrated in Table 3. 
Table 3. The crisp direct-influence matrix.

\begin{tabular}{ccccc}
\hline Dimensions & D1 & D2 & D3 & D4 \\
\hline D1 & 0.000 & 0.625 & 0.575 & 0.525 \\
D2 & 0.575 & 0.000 & 0.675 & 0.525 \\
D3 & 0.450 & 0.675 & 0.000 & 0.475 \\
D4 & 0.700 & 0.725 & 0.650 & 0.000 \\
\hline
\end{tabular}

In addition, the direct-influence matrix is normalized, and this process is shown in Table 4 . In this normalization process, firstly, the totals of the rows are calculated. From these totals, the maximum values are taken into consideration. After that, all the data are rated to these maximum values.

Table 4. The normalized direct-influence matrix.

\begin{tabular}{ccccc}
\hline Dimensions & D1 & D2 & D3 & D4 \\
\hline D1 & 0.000 & 0.301 & 0.277 & 0.253 \\
D2 & 0.277 & 0.000 & 0.325 & 0.253 \\
D3 & 0.217 & 0.325 & 0.000 & 0.229 \\
D4 & 0.337 & 0.349 & 0.313 & 0.000 \\
\hline
\end{tabular}

After creating the normalized direct-influence matrix, the total relation fuzzy matrix is developed. The details of this matrix are stated in Table 5 .

Table 5. The total-relation fuzzy matrix.

\begin{tabular}{ccccc}
\hline Dimensions & D1 & D2 & D3 & D4 \\
\hline D1 & 1.284 & 1.694 & 1.615 & 1.376 \\
D2 & 1.525 & 1.492 & 1.671 & 1.399 \\
D3 & 1.389 & 1.625 & 1.319 & 1.293 \\
D4 & 1.739 & 1.951 & 1.855 & 1.358 \\
\hline
\end{tabular}

With the help of the total-relation fuzzy matrix, the impact-relationship degrees and the weight of the global risk dimensions are calculated. In this process, the equations related to the hesitant Fuzzy DEMATEL are taken into consideration.

Table 6 gives information that the industry-based dimension (D2) has the highest importance because it has the greatest weight (0.261). On the other hand, the economy-based aspect (D1) has the lowest priority because of its minimum weight $(0.242)$ in comparison with other dimensions. This gives us information that the problems regarding the industry level should be solved first in order to decrease the global risk. In addition, we also identified that the dimension of firm-based factors (D2) is the most influenced factor whereas the dimension of vagueness (D4) is the most influencing factor. Rehman et al. (2015) and Wilson (2017) also reached the similar conditions in their studies.

Table 6. The impact-relationship degrees and weights of the global risk dimensions.

\begin{tabular}{cccccc}
\hline Dimensions & $\widetilde{\boldsymbol{D}}_{\boldsymbol{i}}^{\text {def }}$ & $\widetilde{\boldsymbol{R}}_{\boldsymbol{i}}^{\text {def }}$ & $\widetilde{\boldsymbol{D}}_{\boldsymbol{i}}^{\text {def }}+\widetilde{\boldsymbol{R}}_{\boldsymbol{i}}^{\text {def }}$ & $\widetilde{\boldsymbol{D}}_{\boldsymbol{i}}^{\text {def }}-\widetilde{\boldsymbol{R}}_{\boldsymbol{i}}^{\text {def }}$ & Weights \\
\hline D1 & 5.970 & 5.937 & 11.907 & 0.033 & 0.242 \\
D2 & 6.086 & 6.762 & 12.848 & -0.675 & 0.261 \\
D3 & 5.626 & 6.460 & 12.086 & -0.834 & 0.246 \\
D4 & 6.903 & 5.427 & 12.330 & 1.476 & 0.251 \\
\hline
\end{tabular}


Measuring the global risk for the financial crisis with hesitant fuzzy VIKOR and TOPSIS:

In order to measure the global risk for a financial crisis, the hesitant fuzzy VIKOR and hesitant fuzzy TOPSIS approaches are taken into consideration. With respect to the hesitant fuzzy VIKOR method, firstly, the hesitant fuzzy decision matrix is calculated by considering the hesitant fuzzy sets. The details of this matrix are given in Table 7.

Table 7. The collective hesitant fuzzy decision matrix for financial crises.

\begin{tabular}{ccccc}
\hline Alternatives/Criteria & Economy-Based (D1) & Industry-Based (D2) & Firm-Based (D3) & Vagueness (D4) \\
\hline 1973 Oil Crisis (A1) & $\{0.6,0.7,0.8\}$ & $\{0.7,0.8\}$ & $\{0.6,0.7\}$ & $\{0.5,0.6,0.7\}$ \\
1982 Latin American Debt & $\{0.6,0.7,0.8\}$ & $\{0.5,0.6,0.7\}$ & $\{0.6,0.7,0.8\}$ & $\{0.7,0.8\}$ \\
Crisis (A2) & $\{0.7\}$ & $\{0.6,0.7\}$ & $\{0.7,0.8\}$ & $\{0.7,0.8\}$ \\
1997 Asian Financial Crisis (A3) & $\{0.5,0.6\}$ & $\{0.7,0.8\}$ & $\{0.5,0.6,0.7\}$ & $\{0.6,0.7,0.8\}$ \\
2008 Mortgage Crisis (A4) & $\{0.6,0.7,0.8\}$ & $\{0.6,0.7\}$ & $\{0.6,0.7,0.8\}$ & $\{0.6,0.7\}$ \\
\hline
\end{tabular}

Moreover, Table 8 gives information about the $\mathrm{Si}$, $\mathrm{Ri}$, and Qi values. In this circumstance, the Equations (18)-(20) are used.

Table 8. The values of Si, Ri, and Qi with the hesitant fuzzy VIKOR method.

\begin{tabular}{cccc}
\hline Financial Crisis (Alternatives) & Si & Ri & Qi \\
\hline 1973 Oil Crisis (A1) & 0.414 & 0.146 & 0.490 \\
1982 Latin American Debt Crisis (A2) & 0.357 & 0.152 & 0.302 \\
1997 Asian Financial Crisis (A3) & 0.337 & 0.152 & 0.214 \\
2008 Mortgage Crisis (A4) & 0.451 & 0.182 & 1.000 \\
2010 European Debt Crisis (A5) & 0.419 & 0.131 & 0.359 \\
\hline
\end{tabular}

While considering the $\mathrm{Si}, \mathrm{Ri}$, and Qi values, the selected financial crises are ranked for different $\mathrm{v}$ values. The analysis results are given in Table 9.

Table 9. The ranking of the financial crises for the different strategies of maximum group utility with the hesitant fuzzy VIKOR method.

\begin{tabular}{cccccccccccc}
\hline Alternatives & $\mathbf{v}: 0$ & $\mathbf{v : 0 . 1}$ & $\mathbf{v : 0 . 2}$ & $\mathbf{v}: 0.3$ & v:0.4 & v:0.5 & v:0.6 & v:0.7 & v:0.8 & v:0.9 & v:1 \\
\hline A1 & 2 & 2 & 4 & 4 & 4 & 4 & 4 & 4 & 4 & 3 & 3 \\
A2 & 3 & 4 & 3 & 3 & 3 & 2 & 2 & 2 & 2 & 2 & 2 \\
A3 & 4 & 3 & 2 & 2 & 1 & 1 & 1 & 1 & 1 & 1 & 1 \\
A4 & 5 & 5 & 5 & 5 & 5 & 5 & 5 & 5 & 5 & 5 & 5 \\
A5 & 1 & 1 & 1 & 1 & 2 & 3 & 3 & 3 & 3 & 4 & 4 \\
\hline
\end{tabular}

In Table 9, the " $\mathrm{v}$ " values give information about the veto situation among experts. When $\mathrm{v}$ is equal to 0 , it means that there is no consensus among experts. On the other hand, if there is a consensus, the $\mathrm{v}$ value should be equal to 0.5 . Table 9 gives information that, in the case of the experts coming to no consensus, the European debt crisis (A5) is the most influenced crisis in terms of global risks. The main reason behind this is that because European countries could not pay their debts, there was a significant decrease in the credit ratings of the countries and companies. This situation has a negative influence on the effectiveness of the financial system in these countries. Hence, the industries in these countries are affected by this problem. Moreover, the role of the political risk in financial markets is also significant in this condition. In other words, confidence in the European markets has decreased during this crisis. This situation has a strong effect on the risk premium of these countries. In addition to this situation, it can also be determined that the 2008 Mortgage Crisis (A4) is the least influenced crisis in terms of global risks. The main reason for this is that it has the lowest ranking (5) in all cases. 
It can be understood from Table 10 that the 1982 Latin American Debt Crisis (A2) is ranked first. This means that global risks mainly affect this crisis. Because Latin American countries could not pay their debts, the macroeconomic conditions in these countries deteriorated. There were high inflation rates and significant capital outflow from these countries. Because of these issues, the industries of these countries were affected in a negative manner. Consequently, it can be said that this crisis is the most influenced crisis by the global risks in comparison to the others.

Table 10. The ranking of the financial crises with the hesitant fuzzy TOPSIS model.

\begin{tabular}{ccccc}
\hline Financial Crisis (Alternatives) & D+ & D- & $\boldsymbol{R C}_{\boldsymbol{i}}$ & Ranking \\
\hline 1973 Oil Crisis(A1) & 0.108 & 0.106 & 0.495 & 2 \\
1982 Latin American Debt Crisis (A2) & 0.099 & 0.115 & 0.537 & 1 \\
1997 Asian Financial Crisis (A3) & 0.114 & 0.099 & 0.465 & 4 \\
2008 Mortgage Crisis (A4) & 0.130 & 0.083 & 0.389 & 5 \\
2010 European Debt Crisis (A5) & 0.110 & 0.104 & 0.485 & 3 \\
\hline
\end{tabular}

Another important issue of these analyses is that the results of the hesitant fuzzy VIKOR and hesitant fuzzy TOPSIS models are quite different. On the other hand, these two different results are the most similar when the " $v$ " value is equal to 0 . In other words, when the experts do not reach a consensus, the hesitant fuzzy VIKOR and hesitant fuzzy TOPSIS approaches give more coherent results. This situation shows that this analysis is quite appropriate with respect to the hesitant approach.

When there is no consensus among the experts, the ranking of the hesitant fuzzy VIKOR is A5, $\mathrm{A} 1, \mathrm{~A} 2, \mathrm{~A} 3$, and A4. On the other hand, the ranking by the hesitant fuzzy TOPSIS model is A2, A1, $\mathrm{A} 5, \mathrm{~A} 3$, and A4. It can be seen that the difference between these two different approaches is regarding the 1982 Latin American Debt Crisis (A2) and the 2010 European Debt Crisis (A5). This means that by considering the mean group utility and maximal regret, we concluded that the 2010 European Debt Crisis (A5) is the most influenced crisis by global risks. Nevertheless, the 1982 Latin American Debt Crisis (A2) is ranked first when the separation of each alternative from the ideal solution is taken into the consideration.

\section{Discussion and Conclusions}

Global risks give information on the risks that have a negative and significant impact on many different regions in the world at the same time. In addition to this situation, a risk should have an effect on many different industries in order to be accepted as a global risk. Moreover, a global risk includes a higher uncertainty in comparison with other types of risks. Furthermore, the level of negative effects because of global risks should be high as well. As it can be understood from these explanations, global risks may cause important financial crises in the world.

Similar to this aspect, in this study, we aimed to analyze the global risks for different financial crises. For this purpose, the financial crises after the Great Depression in 1929, which have had negative effects on many different regions in the world, were evaluated. Within this scope, five significant financial crises were selected. On the other hand, with respect to global risks, four different dimensions are identified by considering the Global Risk report. Additionally, the hesitant fuzzy DEMATEL, the hesitant fuzzy VIKOR, and the hesitant fuzzy TOPSIS methods are used to reach this objective.

According to the results of the hesitant fuzzy DEMATEL method, we identified that the industry-based dimension (D2) has the highest importance in comparison with the other dimensions. However, we also concluded that the economy-based aspect (D1) has the lowest priority regarding global risk. While considering these aspects, it can be said that, so as to minimize the negative effects of global risk, countries should first focus on the solutions related to the industry level problems.

In addition to this aspect, we also determined that the European debt crisis (A5) and the 1982 Latin American debt crisis (A2) are the most influenced crises by global risk as a result of the hesitant fuzzy VIKOR and hesitant fuzzy TOPSIS approaches. The main reason for this conclusion was that in 
these crises, the macroeconomic conditions of the countries had deteriorated significantly. Because of this, the countries were subject to important economic problems, such as a high inflation rate and a high unemployment rate. These issues had a negative influence on the industries.

Another important point is that the results of the hesitant fuzzy VIKOR and hesitant fuzzy TOPSIS methods are quite different. However, it can also be seen that these two different results are the most similar when the " $\mathrm{v}$ " value is equal to 0 . That is to say, the hesitant fuzzy VIKOR and hesitant fuzzy TOPSIS approaches give more coherent results when the experts do not reach a consensus. This issue gives information that proves that this analysis is quite appropriate regarding the hesitant approach. By analyzing these significant topics, we believe that this study makes a contribution to the literature. Nevertheless, we believe that making a new analysis that covers more financial crises in the future will also be beneficial.

Author Contributions: All authors contributed equally to all aspects of the research reported in this paper.

Funding: This research received no external funding.

Acknowledgments: We are grateful to three anonymous referees, and the editors for their comments and suggestions that have helped to improve considerably the paper; nonetheless, we are of course responsible for all errors and omissions. Finally, the views expressed in this paper are those of the authors and do not necessarily represent the views of their affiliated institutions.

Conflicts of Interest: The authors declare no conflict of interest.

\section{References}

1. Dinçer, H.; Yuksel, S.; Adalı, Z. Relationship between Non-Performing Loans, Industry, and Economic Growth of the African Economies and Policy Recommendations for Global Growth. In Globalization and Trade Integration in Developing Countries; IGI Global: Pennsylvania, PA, USA, 2018; pp. 203-228.

2. Aven, T.; Cox, L.A., Jr. National and global risk studies: How can the field of risk analysis contribute? Risk Anal. 2016, 36, 186-190. [CrossRef] [PubMed]

3. Yüksel, S. Determinants of the credit risk in developing countries after economic crisis: A case of Turkish banking sector. In Global Financial Crisis and Its Ramifications on Capital Markets; Springer: Cham, Switzerland, 2017; pp. 401-415.

4. Golub, S.; Kaya, A.; Reay, M. What were they thinking? The Federal Reserve in the run-up to the 2008 financial crisis. Rev. Int. Polit. Econ. 2015, 22, 657-692. [CrossRef]

5. Keffala, M.R. How using derivatives affects bank stability in emerging countries? Evidence from the recent financial crisis. Res. Int. Bus. Financ. 2015, 35, 75-87. [CrossRef]

6. Knights, D.; McCabe, D. 'Masters of the Universe': Demystifying leadership in the context of the 2008 global financial crisis. Br. J. Manag. 2015, 26, 197-210. [CrossRef]

7. Warlouzet, L. Governing Europe in a Globalizing World: Neoliberalism and Its Alternatives Following the 1973 Oil Crisis; Routledge: Abingdon, UK, 2017.

8. Devlin, R. Debt and Crisis in Latin America: The Supply Side of the Story; Princeton University Press: Princeton, NJ, USA, 2014.

9. Almeida, H.; Kim, C.S.; Kim, H.B. Internal capital markets in business groups: Evidence from the Asian financial crisis. J. Financ. 2015, 70, 2539-2586. [CrossRef]

10. Yüksel, S.; Zengin, S. Leading Indicators of 2008 Global Crisis: An Analysis with Logit and Mars Methods. Finansal Araştırmalar ve Çalı̧malar Dergisi 2016, 8, 495-518. [CrossRef]

11. Broto, C.; Perez-Quiros, G. Disentangling contagion among Sovereign CDS spreads during the European debt crisis. J. Empir. Financ. 2015, 32, 165-179. [CrossRef]

12. Pap, M.; Homolya, D. Measurement and Mitigation of Country Risk: The Role of Quantitative and Qualitative Factors, Insurance Market Trends. In Proceedings of the 8th International Scientific Conference "Future World by 2050", Pula, Croatia, 1-3 June 2017.

13. Nasr, A.B.; Cunado, J.; Demirer, R.; Gupta, R. Country Risk Ratings and Stock Market Returns in BRICS Countries: A Nonlinear Dynamic Approach; No. 201758; University of Pretoria: Pretoria, South Africa, 2017. 
14. Korotaev, A.; Shulgin, S.; Zinkina, Y. Country Risk Analysis Based on Demographic and Socio-Economic Data; No. 031715; Russian Presidential Academy of National Economy and Public Administration: Moskva, Russia, 2017.

15. Acosta, A.; Barráez, D.; Pérez, D.; Urbina, M. Country Risk, Macroeconomic Fundamentals and Uncertainty in Latin American Economies. Monetaria 2015, 3, 147-174.

16. Shostya, A.; Banai, M. Cultural and Institutional Antecedents of Country Risk. Atl. Econ. J. 2017, 45, 351-364. [CrossRef]

17. Avdjiev, S.; Bruno, V.; Koch, C.; Shin, H.S. Dollar exchange rate as a global risk factor: Evidence from investment. In Proceedings of the 2017 IMF Annual Research Conference, Washington, DC, USA, 2-3 November 2017.

18. Mensi, W.; Hammoudeh, S.; Yoon, S.M.; Nguyen, D.K. Asymmetric linkages between BRICS stock returns and country risk ratings: Evidence from dynamic panel threshold models. Rev. Int. Econ. 2016, 24, 1-19. [CrossRef]

19. Liu, C.; Sun, X.; Chen, J.; Li, J. Statistical properties of country risk ratings under oil price volatility: Evidence from selected oil-exporting countries. Energy Policy 2016, 92, 234-245. [CrossRef]

20. Chiu, Y.B.; Lee, C.C. On the Impact of Public Debt on Economic Growth: Does Country Risk Matter? Contemp. Econ. Policy 2017, 35, 751-766. [CrossRef]

21. Wang, P.; Huang, W. The implied growth rates and country risk premium: Evidence from Chinese stock markets. Rev. Quant. Financ. Acc. 2015, 45, 641-663. [CrossRef]

22. Sahi, C.A.I.; Rasheed, A. Impact of sovereign credit rating and country risk on bond market of Pakistan. Paradigms 2017, 11, 54-57. [CrossRef]

23. Lee, C.C. The Impact of Country Risk on Income Inequality: A Multilevel Analysis. Soc. Indic. Res. 2018, 136, 139-162. [CrossRef]

24. Cervelló-Royo, R.; Peiró-Signes, A.; Segarra-Oña, M. How do country risk ratings affect tourism activity? An indirect measure of the environmental awareness of countries. Environ. Eng. Manag. J. 2016, 15, 1489-1499. [CrossRef]

25. Naifar, N. Do global risk factors and macroeconomic conditions affect global Islamic index dynamics? A quantile regression approach. Q. Rev. Econ. Financ. 2016, 61, 29-39. [CrossRef]

26. Jackson, K. Asian Contagion: The Causes and Consequences of a Financial Crisis; Routledge: Abingdon, UK, 2018.

27. Gilchrist, S.; Schoenle, R.; Sim, J.; Zakrajšek, E. Inflation dynamics during the financial crisis. Am. Econ. Rev. 2017, 107, 785-823. [CrossRef]

28. Mera, K.; Renaud, B. Asia's Financial Crisis and the Role of Real Estate; Routledge: Abingdon, UK, 2016.

29. Ferrero, A. House price booms, current account deficits, and low interest rates. J. Money Credit Bank. 2015, 47, 261-293. [CrossRef]

30. Stockhammer, E.; Constantine, C.; Reissl, S. Explaining the Euro Crisis: Current Account Imbalances 2016, Credit Booms and Economic Policy in Different Economic Paradigms; Working Paper, 1617; Post Keynesian Economics Study Group: Fort Mill, SC, USA, 2016.

31. Claessens, S.; Van Horen, N. The impact of the global financial crisis on banking globalization. IMF Econ. Rev. 2015, 63, 868-918. [CrossRef]

32. Ramcharan, R.; Verani, S.; Van den Heuvel, S.J. From Wall Street to main street: The impact of the financial crisis on consumer credit supply. J. Financ. 2016, 71, 1323-1356. [CrossRef]

33. Zouaghi, F.; Sánchez, M.; Martínez, M.G. Did the global financial crisis impact firms' innovation performance? The role of internal and external knowledge capabilities in high and low tech industries. Technol. Forecast. Soc. Chang. 2018, 132, 92-104. [CrossRef]

34. Malik, A.O.; Ghosh, S. Impact of global financial crisis on the Indian economic growth (pre-during-post global meltdown and European Sovereign Debt Crisis Period). Asian J. Res. Bank. Financ. 2017, 7, 36-48. [CrossRef]

35. Ordoñez-Callamand, D.; Gomez-Gonzalez, J.E.; Melo-Velandia, L.F. Sovereign default risk in OECD countries: Do global factors matter? N. Am. J. Econ. Financ. 2017, 42, 629-639. [CrossRef]

36. Berger, T.; Grabert, S.; Kempa, B. Global macroeconomic uncertainty. J. Macroecon. 2017, 53, 42-56. [CrossRef]

37. Rehman, M.S.U.; Rashid, N.; Ashfaq, M.; Saif, A.; Ahmad, N.; Han, J.I. Global risk of pharmaceutical contamination from highly populated developing countries. Chemosphere 2015, 138, 1045-1055. [CrossRef] [PubMed] 
38. Wilson, J.M. The future of brand protection: Responding to the global risk. J. Brand Manag. 2017, 24, $271-283$. [CrossRef]

39. Abune'Meh, M.; El Meouche, R.; Hijaze, I.; Mebarki, A.; Shahrour, I. Optimal construction site layout based on risk spatial variability. Autom. Constr. 2016, 70, 167-177. [CrossRef]

40. Wilson, J.M.; Kinghorn, R. A total business approach to the global risk of product counterfeiting. Glob. Edge Bus. Rev. 2016, 10, 1-6.

41. Talarico, L.; Springael, J.; Sörensen, K.; Talarico, F. A large neighbourhood metaheuristic for the risk-constrained cash-in-transit vehicle routing problem. Comput. Oper. Res. 2017, 78, 547-556. [CrossRef]

42. Awasthi, A.; Govindan, K.; Gold, S. Multi-tier sustainable global supplier selection using a fuzzy AHP-VIKOR based approach. Int. J. Prod. Econ. 2018, 195, 106-117. [CrossRef]

43. Moser, S.C.; Kasperson, R.E. Introduction: Risk conundrums in a fast and complex world. In Risk Conundrums; Routledge: Abingdon, UK, 2017.

44. Balbás, A.; Balbás, B.; Balbás, R.; Heras, A. Optimal reinsurance under risk and uncertainty. Insurance 2015, 60, 61-74. [CrossRef]

45. Hsu, C.H.; Wang, F.K.; Tzeng, G.H. The best vendor selection for conducting the recycled material based on a hybrid MCDM model combining DANP with VIKOR. Resour. Conserv. Recycl. 2012, 66, 95-111. [CrossRef]

46. Chiu, W.Y.; Tzeng, G.H.; Li, H.L. A new hybrid MCDM model combining DANP with VIKOR to improve e-store business. Knowl.-Based Syst. 2013, 37, 48-61. [CrossRef]

47. Si, S.L.; You, X.Y.; Liu, H.C.; Zhang, P. DEMATEL technique: A systematic review of the state-of-the-art literature on methodologies and applications. Math. Probl. Eng. 2018, 2018, 3696457. [CrossRef]

48. Dinçer, H.; Yüksel, S.; Martínez, L. Balanced scorecard-based Analysis about European Energy Investment Policies: A hybrid hesitant fuzzy decision-making approach with Quality Function Deployment. Expert Syst. Appl. 2019, 115, 152-171. [CrossRef]

49. Gitinavard, H.; Mousavi, S.M.; Vahdani, B. Soft computing based on hierarchical evaluation approach and criteria interdependencies for energy decision-making problems: A case study. Energy 2017, 118, 556-577. [CrossRef]

50. Wu, S.M.; Liu, H.C.; Wang, L.E. Hesitant fuzzy integrated MCDM approach for quality function deployment: A case study in electric vehicle. Int. J. Prod. Res. 2017, 55, 4436-4449. [CrossRef]

51. Zhang, N.; Wei, G. Extension of VIKOR method for decision making problem based on hesitant fuzzy set. Appl. Math. Model. 2013, 37, 4938-4947. [CrossRef]

52. Liao, H.; Xu, Z.A. VIKOR-based method for hesitant fuzzy multi-criteria decision making. Fuzzy Opt. Decis. Making 2013, 12, 373-392. [CrossRef]

53. Ren, Z.; Xu, Z.; Wang, H. Dual hesitant fuzzy VIKOR method for multi-criteria group decision making based on fuzzy measure and new comparison method. Inf. Sci. 2017, 388, 1-16. [CrossRef]

54. Zhang, F.; Luo, L.; Liao, H.; Zhu, T.; Shi, Y.; Shen, W. Inpatient admission assessment in West China Hospital based on hesitant fuzzy linguistic VIKOR method. J. Intell. Fuzzy Syst. 2016, 30, 3143-3154. [CrossRef]

55. Hwang, C.L.; Yoon, K. Methods for multiple attribute decision making. In Multiple Attribute Decision Making; Springer: Berlin/Heidelberg, Germany, 1981; pp. 58-191.

56. Cevik Onar, S.; Oztaysi, B.; Kahraman, C. Strategic decision selection using hesitant fuzzy TOPSIS and interval type-2 fuzzy AHP: A case study. Int. J. Comput. Intell. Syst. 2014, 7, 1002-1021. [CrossRef]

57. Yavuz, M.; Oztaysi, B.; Onar, S.C.; Kahraman, C. Multi-criteria evaluation of alternative-fuel vehicles via a hierarchical hesitant fuzzy linguistic model. Expert Syst. Appl. 2015, 42, 2835-2848. [CrossRef]

58. Senvar, O.; Otay, I.; Bolturk, E. Hospital site selection via hesitant fuzzy TOPSIS. PapersOnLine 2016, 49, 1140-1145. [CrossRef]

(C) 2018 by the authors. Licensee MDPI, Basel, Switzerland. This article is an open access article distributed under the terms and conditions of the Creative Commons Attribution (CC BY) license (http:/ / creativecommons.org/licenses/by/4.0/). 